\title{
Near-Infrared Time-Resolved Spectroscopy for Assessing Brown Adipose Tissue Density in Humans: A Review
}

\author{
Takafumi Hamaoka ${ }^{1 *}$, Shinsuke Nirengi ${ }^{2,3}$, Sayuri Fuse ${ }^{1}$, Shiho Amagasa ${ }^{4}$, Ryotaro Kime ${ }^{1}$, \\ Miyuki Kuroiwa ${ }^{1}$, Tasuki Endo ${ }^{1}$, Naoki Sakane ${ }^{2}$, Mami Matsushita ${ }^{5}$, Masayuki Saito ${ }^{6}$, \\ Takeshi Yoneshiro ${ }^{7}$ and Yuko Kurosawa ${ }^{1}$

\begin{abstract}
${ }^{1}$ Department of Sports Medicine for Health Promotion, Tokyo Medical University, Tokyo, Japan, ${ }^{2}$ Division of Preventive Medicine, National Hospital Organization Kyoto Medical Center, Clinical Research Institute, Kyoto, Japan, ${ }^{3}$ Dorothy M. Davis Heart and Lung Research Institute, Wexner Medical Center, Columbus, OH, United States, ${ }^{4}$ Department of Preventive Medicine and Public Health, Tokyo Medical University, Tokyo, Japan, ${ }^{5}$ Department of Nutrition, Tenshi College, Sapporo, Japan, ${ }^{6}$ Faculty of Veterinary Medicine, Hokkaido University, Sapporo, Japan, ${ }^{7}$ Diabetes Center, University of California San Francisco, San Francisco, CA, United States
\end{abstract}

\section{OPEN ACCESS}

Edited by:

Jennifer L. Miles-Chan,

University of Auckland, New Zealand

Reviewed by:

Francisco Miguel Acosta Manzano,

Ministry of Economy and

Competitiveness, Spain

Valentina Hartwig,

Italian National Research Council, Italy

${ }^{*}$ Correspondence:

Takafumi Hamaoka kyp02504@nifty.com

Specialty section

This article was submitted to

Obesity,

a section of the journal

Frontiers in Endocrinology

Received: 04 February 2020

Accepted: 08 April 2020

Published: 19 May 2020

Citation:

Hamaoka T, Nirengi S, Fuse $S$ Amagasa S, Kime R, Kuroiwa M, Endo T, Sakane N, Matsushita M, Saito M, Yoneshiro $T$ and Kurosawa $Y$ (2020) Near-Infrared Time-Resolved Spectroscopy for Assessing Brown Adipose Tissue Density in Humans:

A Review. Front. Endocrinol. 11:261. doi: 10.3389/fendo.2020.00261
Brown adipose tissue (BAT) mediates adaptive thermogenesis upon food intake and cold exposure, thus potentially contributing to the prevention of lifestyle-related diseases. ${ }^{18}$ F-fluorodeoxyglucose (FDG)-positron emission tomography (PET) with computed tomography (CT) $\left({ }^{18} \mathrm{FDG}-\mathrm{PET} / \mathrm{CT}\right)$ is a standard method for assessing BAT activity and volume in humans. ${ }^{18}$ FDG-PET/CT has several limitations, including high device cost and ionizing radiation and acute cold exposure necessary to maximally stimulate BAT activity. In contrast, near-infrared spectroscopy (NIRS) has been used for measuring changes in $\mathrm{O}_{2}$-dependent light absorption in the tissue in a non-invasive manner, without using radiation. Among NIRS, time-resolved NIRS (NIRTRS) can quantify the concentrations of oxygenated and deoxygenated hemoglobin ([oxy- $\mathrm{Hb}]$ and [deoxy-Hb], respectively) by emitting ultrashort (100 ps) light pulses and counts photons, which are scattered and absorbed in the tissue. The basis for assessing BAT density (BAT-d) using NIRTRS is that the vascular density in the supraclavicular region, as estimated using $\mathrm{Hb}$ concentration, is higher in BAT than in white adipose tissue. In contrast, relatively low-cost continuous wavelength NIRS (NIR Cws) is employed for measuring relative changes in oxygenation in tissues. In this review, we provide evidence for the validity of NIRTRS and

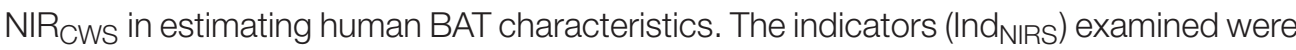
$[0 x y-H b]_{\text {sup }}$, [deoxy-Hb] $]_{\text {sup }}$, total hemoglobin [total-Hb] $]_{\text {sup }}, \mathrm{Hb} \mathrm{O}_{2}$ saturation $\left(\mathrm{StO}_{2 \text { sup }}\right)$, and reduced scattering coefficient $\left(\mu_{\mathrm{s}}^{\prime}\right.$ sup $)$ in the supraclavicular region, as determined by NIRTRS, and relative changes in corresponding parameters, as determined by $N I R_{C W S}$. The evidence comprises the relationships between the Ind $d_{\text {NIRS }}$ investigated and those determined by ${ }^{18} \mathrm{FDG}-\mathrm{PET} / \mathrm{CT}$; the correlation between the Ind $_{\text {NIRS }}$ and cold-induced thermogenesis; the relationship of the Ind $_{\text {NIRS }}$ to parameters measured by ${ }^{18}$ FDG-PET/CT, which responded to seasonal temperature fluctuations; the relationship of the Ind NIRS $_{\text {and plasma lipid metabolites; the analogy of the Ind }}$ NIRS to chronological and anthropometric data; and changes in the Ind NIRS following thermogenic food supplementation. The $[\text { total-Hb] }]_{\text {sup }}$ and $[\mathrm{oxy}-\mathrm{Hb}]_{\text {sup }}$ determined by NIRTRS, but not 
parameters determined by NIR $\mathrm{R}_{\text {cws }}$, exhibited significant correlations with cold-induced thermogenesis parameters and plasma androgens in men in winter or analogies to ${ }^{18}$ FDG-PET. We conclude that NIRTRS can provide useful information for assessing BAT-d in a simple, rapid, non-invasive way, although further validation study is still needed.

Keywords: brown adipose tissue, adaptive thermogenesis, thermogenic food ingredients, androgens, lipid metabolites, seasonal temperature changes, non-invasive, ${ }^{18} \mathrm{~F}$-fluorodeoxyglucose-positron emission tomography

\section{INTRODUCTION}

Human adipose tissues are of a variety of types, such as white (WAT) and brown adipose tissue (BAT) (1). WAT is capable of depositing extra-energy as triglyceride droplets under conditions where energy intake is greater than its expenditure. In contrast, BAT promotes non-shivering thermogenesis to respond to decreases in core body temperature and, in contrast to WAT, is characterized by an abundance of mitochondria and vasculature. BAT has been extensively investigated in animals, and it has been determined that BAT-specific uncoupling protein (UCP)1 , mainly stimulated upon $\beta_{3}$-adrenergic activation by cold and/or dietary intervention, enables BAT to dissipate free energy to heat by proton discharge through the inner mitochondrial membrane $(2,3)$. BAT has drawn renewed attention since 2009, with several papers being published that report the existence of BAT deposits in adult humans (4-7), which had previously been thought to be lost during the process of maturation. Human BAT is reported to be related to lower adiposity [body mass index (BMI), the percentage of whole body fat $(\% \mathrm{BF})$, and visceral fat area (VFA)] (6-9) and increased glucose sensitivity (10). In experimental studies, repeated exposure to cold environment enhanced the BAT activity and improved glucose tolerance in obese counterparts (11) and patients with type 2 diabetes mellitus (12) as well as in healthy individuals $(9,13,14)$. Thus, increasing BAT activity or volume may aid in combatting obesity and chronic diseases, such as type 2 diabetes mellitus.

It is well-known in humans that BAT can be evaluated by ${ }^{18}$ F-fluorodeoxyglucose (FDG)-positron emission tomography (PET) with computed tomography (CT) $\left({ }^{18} \mathrm{FDG}-\mathrm{PET} / \mathrm{CT}\right)$ under cold-stimulated environments $(3,4,6,15)$. However, ${ }^{18}$ FDG-PET/CT has several limitations, including the enormous cost of the device and ionizing radiation exposure, and acute cold exposure-necessary to maximally stimulate BAT activity

\footnotetext{
Abbreviations: adjStO $\mathrm{S}_{2}$, adjusted supraclavicular $\mathrm{StO}_{2} ; \mathrm{AR}, \quad \beta 3$-adrenergic receptor; BAT, brown adipose tissue; BAT-d, vascular or mitochondrial density in BAT; BMI, body mass index; CIT, cold-induced thermogenesis; CT, computed tomography; deoxy-Hb, deoxygenated $\mathrm{Hb}$; FDG, ${ }^{18}$ F-fluorodeoxyglucose; $\mathrm{Hb}$, hemoglobin; NE, norepinephrine; NIRS, near-infrared spectroscopy; NIR ${ }_{C W S}$, NIR continuous-wave spectroscopy; NIRTRS, NIR time-resolved spectroscopy; oxy- $\mathrm{Hb}$, oxygenated $\mathrm{Hb} ; \mathrm{StO}_{2}, \mathrm{Hb} \mathrm{O}_{2}$ saturation; $\mathrm{PET}$, positron emission tomography; ROC, receiver operating characteristic; total-Hb, total hemoglobin; TRP, transient receptor potential channels; $\mathrm{SUV}_{\max }$, maximal standardized uptake value; $\mathrm{SUV}_{\text {mean }}$, mean standardized uptake value; WAT, white adipose tissue; $\mu_{\mathrm{a}}$, absorption coefficient; $\mu_{\mathrm{s}}{ }^{\prime}$, reduced scattering coefficient.
}

(16), which make a longitudinal ${ }^{18}$ FDG-PET/CT study difficult and disrupt interventional research, specifically longitudinal ones in humans. Cold exposure is primarily required in ${ }^{18} \mathrm{FDG}-$ $\mathrm{PET} / \mathrm{CT}$ studies to activate human BAT, and various protocols have been applied in the past. While standardized guidelines have recently been proposed, differences between protocols remain a significant obstacle to the comparison of observations from different studies (17).

Other non-invasive technologies have been utilized for evaluating BAT characteristics in humans, such as magnetic resonance imaging (MRI) (18, 19), local skin thermal measurements (19), infrared thermography (20), and contrast ultrasound (21). A recent review on the detection of BAT using these non-invasive technologies can be found elsewhere (22). Regarding MRI technologies, proton-density fat fraction (PDFF) values are widely used to distinguish BAT from WAT $(23,24)$. However, the PDFF range in the supraclavicular region widely varies among individuals, which makes the differentiation of BAT from WAT difficult, although several new technologies, such as the measurement of $\mathrm{T} 2 *$ relaxation and diffusion-weighted imaging are under investigation (22). The local skin thermal measurements have been used for monitoring cold-induced temperature changes in the supraclavicular skin with infrared thermography $(25,26)$. However, heat measurements could be influenced by the tissue conductive properties and thickness of the subcutaneous adipose tissue (27), and the individual vasomotor response (28); these evaluation obstacles should be solved in the future.

In addition, near-infrared spectroscopy (NIRS) is a relatively newly introduced methodology to monitor BAT properties (29). The basis for the application of NIRS to evaluate BAT properties is that the microvascular bed, as evaluated by total hemoglobin $(\mathrm{Hb})$ concentration [total- $\mathrm{Hb}]_{\text {sup }}$ in the supraclavicular region, is more abundant in BAT than in WAT (30). Furthermore, NIR time-resolved spectroscopy (NIR TRS ) may be used to assess the density of the microvasculature as well as mitochondrial content in BAT by measuring the reduced scattering coefficient $\left(\mu_{\mathrm{s}}^{\prime}\right)$, which reflects the in vitro mitochondrial content (31). BAT is a highly innervated tissue and is also highly perfused when exposed to cold (32). As the concentrations of oxygenated and deoxygenated $\mathrm{Hb}$ in the supraclavicular region $\left([\mathrm{oxy}-\mathrm{Hb}]_{\text {sup }}\right.$ and $[\text { deoxy-Hb }]_{\text {sup }}$, respectively) are likely to change (especially [total-Hb] $]_{\text {sup }}$, which reflects blood volume), it could be a valid measure of BAT vasculature.

The purpose of this article is to provide evidence concerning the ability of NIRS to evaluate BAT characteristics in humans. In 
this review, we included studies examining BAT characteristics using NIRS in humans: most studies used $\operatorname{NIR}_{\text {TRS }}$ (29, 33-39), a technology to quantify both absolute tissue absorption and scattering characteristics, while some utilized NIR continuous wave spectroscopy $\left(\mathrm{NIR}_{\mathrm{CWS}}\right)$, an inexpensive technology that only provides relative values of tissue oxygenation $(32,40)$. First, we present how NIRS functions to evaluate tissue oxygenation and blood volume. Then, we provide data indicating whether BAT characteristics can be evaluated using $\mathrm{NIR}_{\mathrm{CWS}}$. The main body of the paper presents a series of evidence for $\mathrm{NIR}_{\mathrm{TRS}}$ to assess BAT characteristics. The evidence tested comprises (1) the relationship between parameters determined using NIRS and those measured by ${ }^{18} \mathrm{FDG}-\mathrm{PET} / \mathrm{CT}$, (2) correlations between the NIRS parameters and cold-induced thermogenesis (CIT), (3) correspondence of the NIRS parameters to those reported using ${ }^{18} \mathrm{FDG}-\mathrm{PET} / \mathrm{CT}$ regarding chronological and anthropometric data, (4) the correspondence between NIRS parameters and those reported with ${ }^{18} \mathrm{FDG}-\mathrm{PET} / \mathrm{CT}$ in response to ambient temperature fluctuations, (5) the relationship between parameters determined using NIRS and plasma lipid metabolites, and (6) changes in NIRS parameters induced by supplementation with evidence-based thermogenic functional ingredients.

\section{HOW NIRS FUNCTIONS AS EVALUATING TISSUE OXYGENATION AND BLOOD VOLUME}

NIRS provides non-invasive monitoring of tissue oxygen and $\mathrm{Hb}$ dynamics in vivo (41-45). NIRS is able to monitor changes in $\mathrm{O}_{2}$-dependent light absorption in the heme in the red blood cells circulating in biological tissues (46). There are mainly three types of NIRS devices: NIR $\mathrm{CWS}_{\text {, }}$ $\mathrm{NIR}_{\mathrm{TRS}}$, phase modulation NIR spectroscopy (NIR $\mathrm{PMS}_{\text {), }}$ etc. (46-48). The most popular NIRS devices use NIR $\mathrm{CWS}_{\mathrm{S}}$ that outputs only the qualitative tissue oxygenation. To calculate the changes in [oxy-Hb], [deoxy-Hb], [total-Hb], and $\mathrm{Hb} \mathrm{O} \mathrm{O}_{2}$ saturation $\left(\mathrm{StO}_{2}\right)$ using $\mathrm{NIR}_{\mathrm{CWS}}$, a combination of multiple-wavelengths can be adopted in accordance with the Beer-Lambert law. The main reason why quantitative data cannot be provided as continuous NIR light path traveled through tissues is unknown (42-45). However, spatially resolved NIRS (a type of $\mathrm{NIR}_{\mathrm{CWS}}$ ) is able to provide quantitative values considering several assumptions, although it is still unable to provide the tissue absorption and scattering properties.

On the other hand, NIR TRS $_{\text {and NIR }}$ PMS are more accurate, as they can quantify both tissue absorption and scattering characteristics. NIRTRS emits ultrafast (100 ps) light pulses from the skin surface and measures the photon distributions across the biological tissue with a 2 - to $4-\mathrm{cm}$ distance from the light emission. NIR $\mathrm{NRS}_{\text {is }}$ is able to quantitatively measure the absorption coefficient $\left(\mu_{\mathrm{a}}\right), \mu_{\mathrm{s}}{ }^{\prime}$, and then calculates light path length, tissue [oxy-Hb], [deoxy-Hb], [total- $\mathrm{Hb}$ ], and $\mathrm{StO}_{2}$ $(44,45,48)$. The validity of the signal obtained by NIR CWS $_{\text {and }}$ $\mathrm{NIR}_{\text {TRS }}$ has been confirmed in an in vitro experiment using highly scattering Intralipid ${ }^{\mathrm{TM}}(43,44)$. Using this system, $\mu_{\mathrm{a}}$ in the NIR range was found to be strongly correlated with [total-Hb] $(43,48)$. Furthermore, the study found a significant relationship between $\mu_{\mathrm{s}}^{\prime}$ at $780 \mathrm{~nm}$ and the homogenized tissue mitochondrial concentration (31).

\section{STUDIES USING NIR}

Prior to the NIR $\mathrm{TRS}_{\mathrm{T} S}$ study on human BAT, one study attempted to correlate oxygen dynamics using $\mathrm{NIR}_{\mathrm{CWS}}$ and BAT parameters (32). In this cross-sectional study, adult human subjects (25 subjects; 15 women and 10 men; mean age \pm SD, $30 \pm 7$ years) were assigned into high- (BMI, $22.1 \pm 3.1)$ and lowBAT groups (BMI, $24.7 \pm 3.9$ ) based on the levels of ${ }^{18}$ F-FDG uptake in the cervical-supraclavicular region. It employed tripleoxygen PET scans $\left(\mathrm{H}_{2}^{15} \mathrm{O}, \mathrm{C}^{15} \mathrm{O}\right.$, and $\left.{ }^{15} \mathrm{O}_{2}\right)$ and daily energy expenditure measurements under resting and mild cold $\left(15.5^{\circ} \mathrm{C}\right)$ room conditions for $60 \mathrm{~min}$ using indirect calorimetry (32). They used a NIR ${ }_{\text {Cws }}$ parameter, adjusted supraclavicular $\mathrm{StO}_{2}$ $\left(\operatorname{adj} \mathrm{StO}_{2}\right)$, a balance between oxygen supply and uptake. In the high-BAT group, there was a significant negative correlation between oxygen consumption determined by PET scans and $\operatorname{adjStO}_{2}\left(p=0.02, r^{2}=0.46\right)$ in the supraclavicular region at rest and after the exposure to cold, indicating increased oxygen uptake in highly active BAT (32). However, it detected a limited effect on the difference in adjStO $\mathrm{O}_{2}$ between the two groups (32). It should be noted that the study presented several limitations to consider when interpreting its results: (1) a non-individualized cooling protocol was used; (2) only one NIR $\mathrm{CWS}$ parameter, adjStO ${ }_{2}$, was used in the analysis; and (3) no kinetics data determined by the NIR CWs were provided.

Recently, in young healthy women, a study using the standardized cold exposure aimed to investigate the association

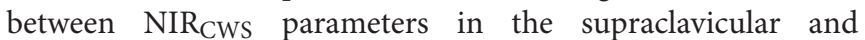
forearm regions and BAT capacity assessed by ${ }^{18}$ FDG-PET/CT (40). Briefly, the subjects arrived at the laboratory (a room temperature of $19.5-20^{\circ} \mathrm{C}$ ) and wore a temperature-controlled water circulation cooling vest for $60 \mathrm{~min}$, and the individual temperature to be exposed was determined, namely at $\sim 4^{\circ} \mathrm{C}$ above the threshold of shivering, $48-72 \mathrm{~h}$ prior to the ${ }^{18} \mathrm{FDG}-$ PET/CT measurements. No association was found between any NIR ${ }_{C W S}$ indicators and maximal standardized uptake value $\left(\mathrm{SUV}_{\max }\right)$ and mean standardized uptake value $\left(\mathrm{SUV}_{\text {mean }}\right)$ of the radioactivity both under thermoneutral and cold conditions.

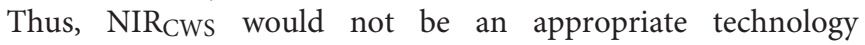
to evaluate BAT capacity in this demographic. The lack of significant association between NIR $\mathrm{NWS}_{\text {s }}$ parameters is mainly due to differences in the instrumentation to that used in NIR $\mathrm{NRS}_{\text {, }}$ which provides absolute values for tissue hemodynamics. Furthermore, NIR CWS permits an $\sim 15 \mathrm{~mm}$ depth of light penetration at a $30 \mathrm{~mm}$ input-output setups (44). However, the mean photon penetration would be deeper $(\sim 20 \mathrm{~mm}$ at the 30-mm input-output setups) and wider when NIR $_{\text {TRS }}$ is used (49), which influences the differences in sensitivity between $\mathrm{NIR}_{\text {CWS }}$ and $\mathrm{NIR}_{\mathrm{TRS}}$ with respect to BAT detection. Table $\mathbf{1}$ shows the relationship between $[\mathrm{oxy}-\mathrm{Hb}]_{\text {sup }},[\text { deoxy- } \mathrm{Hb}]_{\text {sup }}$, 


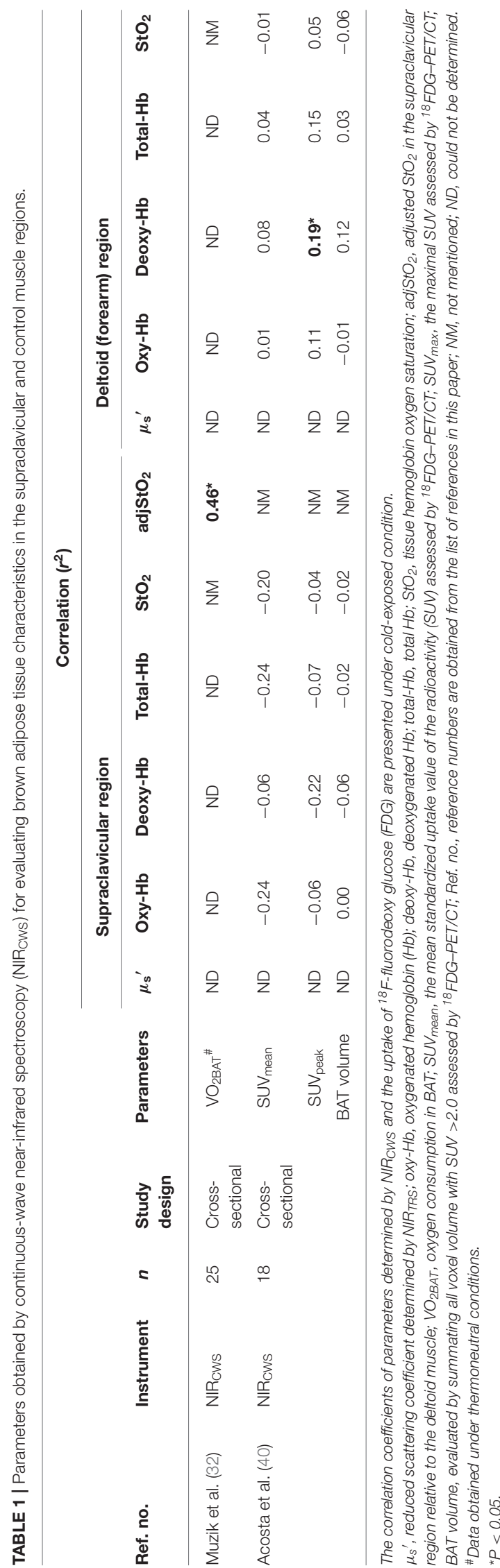

[total- $\mathrm{Hb}]_{\text {sup }}, \mathrm{StO}_{2 \text { sup }}$, and adj $\mathrm{StO}_{2 \text { sup }}$ determined by $\mathrm{NIR}_{\mathrm{CWS}}$ and ${ }^{18} \mathrm{FDG}-\mathrm{PET} / \mathrm{CT}$ parameters $\left(\mathrm{SUV}_{\max }\right.$ and $\mathrm{SUV}_{\text {mean }}$ ), which have been documented in previous studies $(32,40)$. The only NIR ${ }_{C W S}$ parameter found to be significantly correlated with a ${ }^{18} \mathrm{FDG}$-PET/CT parameter, cold-induced oxygen uptake by $\mathrm{BAT}$, is adj $\mathrm{StO}_{2}$, and only in the high-BAT group.

Taken together, the studies using $\operatorname{NIR}_{\text {CWS }}(32,40)$ present potential limitations beyond the fact that it cannot evaluate the absorption and scattering properties of the tissue, including that it is more sensitive to changes in the skin blood flow than NIRTRS $(32,40)$. Therefore, NIR $\mathrm{NWS}_{\text {S }}$ does not seem to be a valid measure for BAT function although emphasis should be placed in the need for further research examining this type of NIRS.

\section{STUDIES USING NIRTRS Correlation Between Parameters Determined by NIRTRS and ${ }^{18}$ FDG-PET/CT Parameters}

It is speculated that, as BAT exhibits higher microvascular density and mitochondrial contents compared to WAT, NIR TRS can be used for assessing the density of microvascular or mitochondrial content in BAT (BAT-d) by measuring [total$\mathrm{Hb}]_{\text {sup }}$ and $\mu_{\mathrm{s}}^{\prime}$ in the supraclavicular region $\left(\mu_{\mathrm{s}}^{\prime}\right.$ sup $)$, which reflects the in vitro mitochondrial content (31). It may be expected that BAT would exhibit higher values for [total$\mathrm{Hb}]_{\text {sup }}$ and $\mu_{\mathrm{s}}^{\prime}$ sup than those exhibited by WAT. As NIR TRS measures the average tissue hemoglobin concentration in a volume of $4 \mathrm{~cm}^{3}$ with a 3 -cm optode separation (50), the ${ }^{18} \mathrm{FDG}-$ $\mathrm{PET} / \mathrm{CT}$-determined $\mathrm{SUV}_{\text {mean }}$ is the most appropriate indicators for comparison to those determined using NIR $\mathrm{NRS}_{\mathrm{TR}}$. Although the use of other radiotracer techniques, such as triple-oxygen scans $\left(\mathrm{H}_{2}^{15} \mathrm{O}, \mathrm{C}^{15} \mathrm{O}\right.$, and $\left.{ }^{15} \mathrm{O}_{2}\right)$ would be more appropriate to reflect BAT activity, ${ }^{18} \mathrm{FDG}-\mathrm{PET} / \mathrm{CT}$ has been mostly used for determination of BAT activity owing to routine availability in a clinical science setup. First, 18 healthy male subjects (20.3 \pm 1.8 years and BMI of $23.9 \pm 3.1 \mathrm{~kg} / \mathrm{m}^{2}$ ) were recruited to examine changes in NIR TRS parameters under acute cold environment. The $[\mathrm{oxy}-\mathrm{Hb}]_{\text {sup }}$, [deoxy-Hb $]_{\text {sup }}$, $[\text { total- } \mathrm{Hb}]_{\text {sup }}$, $\mathrm{StO}_{2 \text { sup }}$, and $\mu_{\mathrm{s}}^{\prime}$ sup were compared between a room temperature under thermoneutral conditions and cold conditions $\left(19^{\circ} \mathrm{C}\right)$ for $2 \mathrm{~h}$. As there was no change in the [total- $\mathrm{Hb}]_{\text {sup }}$ and $\mu_{\mathrm{s}}^{\prime}$ sup at $19^{\circ} \mathrm{C}$ compared to baseline conditions measured at $27^{\circ} \mathrm{C}$, NIR ${ }_{\text {TRS }}$ can be used without the necessity of cold exposure (29). Second, to test this hypothesis, [total-Hb] $]_{\text {sup }}$ and $\mu_{\text {s sup }}^{\prime}$ were compared to the $\mathrm{SUV}_{\text {mean }}$ assessed by ${ }^{18} \mathrm{FDG}-\mathrm{PET} / \mathrm{CT}$ (29) in a cross-sectional design. Twenty-nine healthy male subjects $\left(23.3 \pm 2.2\right.$ years and BMI of $\left.21.6 \pm 1.8 \mathrm{~kg} / \mathrm{m}^{2}\right)$ were recruited to evaluate the relationship between $S_{U V}$ mean

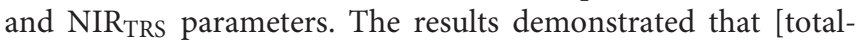
$\mathrm{Hb}]_{\text {sup }}$ and $\mu_{\mathrm{s}}^{\prime}$ sup under warm environment is significantly correlated with the SUV $\mathrm{S}_{\text {mean }}$ under cold environment but only in the supraclavicular fossa, a region of BAT located (29). Other parameters, except adj $\mathrm{StO}_{2}$ specifically in the supraclavicular region, also showed significant correlation with $\mathrm{SUV}_{\max }$ and $\mathrm{SUV}_{\text {mean }}$ under cold environment (Table 2). Collectively, the 
$[\text { total-Hb }]_{\text {sup }}$, $[\mathrm{oxy}-\mathrm{Hb}]_{\text {sup }}$, and $[\mathrm{deoxy}-\mathrm{Hb}]_{\text {sup }}$ show significant correlations to BAT activity determined by ${ }^{18} \mathrm{FDG}-\mathrm{PET} / \mathrm{CT}$. $\mathrm{StO}_{2 \text { sup }}$, however, proved to be inferior, and adjStO $\mathrm{S}_{2}$ was completely insensitive to changes in BAT activity (Table 2).

A 2-h cold exposure doubles the BAT blood flow (32), which appeared to be inconsistent with our observations. In an attempt to interpret this apparent discrepancy, we speculated that NIR $_{\text {TRS }}$ parameters are susceptible to the change in the volume but less sensitive to the change in the flow. The blood flow can be calculated by multiplying the blood flow velocity by the cross-sectional area of the vessel (the volume). There is presently a lack of $\mathrm{NIR}_{\mathrm{TRS}}$-derived data concerning blood flow in BAT. Alternatively, while muscle blood flow increases by some 10 -fold during peak exercise $(51,52)$, [total$\mathrm{Hb}$ ], an indicator of blood volume, monitored by NIRTRS elevates only 1.1-fold (43). Thus, the change in blood volume measurable by NIRTRS is marginal compared to increases in blood flow velocity during metabolic activation. Collectively, both $\mu_{\mathrm{s}}^{\prime}$ sup and [total-Hb] sup were evaluated using the NIRTRS technique can be applied to assess BAT-d in humans and are equivalent to the active BAT intensity or the BAT volume, as measured by ${ }^{18} \mathrm{FDG}-\mathrm{PET} / \mathrm{CT}$ under cold environment (29). Usually, to assign participants into high-BAT $($ BAT $[+])$ and low-BAT (BAT [-]) groups, a cutoff value of 2.0 for $\mathrm{SUV}_{\text {mean }}$ is applied. The accuracy of [total-Hb] sup or $\mu_{s}^{\prime}$ sup in representing BAT activity was analyzed. Accordingly, the area under the receiver operating characteristic (ROC) curve was determined by $\mathrm{SUV}_{\text {mean }}$ of 2.0 nearest to $(0,1)$ for $\mu_{\mathrm{s}}^{\prime}$ sup and [total$\mathrm{Hb}]_{\text {sup }}(29)$. When $74.0 \mu \mathrm{M}$ or $6.8 \mathrm{~cm}^{-1}$ was selected as the cutoff value, meaning that $[\text { total- } \mathrm{Hb}]_{\text {sup }}$ or $\mu_{\mathrm{s}}^{\prime}$ sup larger than $74.0 \mu \mathrm{M}$ or $6.8 \mathrm{~cm}^{-1}$, respectively, are regarded as BAT [+], ROC analysis yields results that are very good when compared to $\mathrm{SUV}_{\text {mean }}(29)$.

\section{Correlation Between Parameters Determined by NIR TRS and CIT}

It is well-documented in rodents that the upregulation of the UCP-1 in brown adipocytes upon cold increases whole body oxygen consumption, termed as CIT. Although several authors have shown that CIT does not always reflect BAT activity (53), that the contribution of BAT thermogenesis to CIT is marginal ( $\sim 10 \mathrm{kcal} /$ day when maximally activated) (54), and no correlation is found between BAT and CIT (55), the magnitude of CIT is related to the amount of BAT activity and/or volume $(9,56-59)$. Thus, having already observed a significant correlation between $\mathrm{NIR}_{\mathrm{TRS}}$ parameters and $\mathrm{SUV}_{\text {mean }}$ assessed by ${ }^{18} \mathrm{FDG}-\mathrm{PET} / \mathrm{CT}$ (29) in humans, the validity of NIR $_{\text {TRS }}$ parameters were further examined by comparing [total$\mathrm{Hb}]_{\text {sup }}$ and $\mu_{\mathrm{s}}^{\prime}$ sup to CIT in healthy individuals [age of 20.0 (median), 19.0 (the first quartile), and 21.0 (the third quartile) year; BMI of $24.2(21.6,25.7) \mathrm{kg} / \mathrm{m}^{2}$ ] with [total- $\left.\mathrm{Hb}\right]_{\text {sup }}$ of $50-125 \mu \mathrm{M}$ in a cross-sectional study (37). The participants sat for $20 \mathrm{~min}$ at $27^{\circ} \mathrm{C}$ with a light clothing, and $\mathrm{NIR}_{\mathrm{TRS}}$ measurements were conducted for $5 \mathrm{~min}$ after fasting for $6-$ $12 \mathrm{~h}$. Then, the participants were tested at room temperature of 
TABLE 3 | Relationship between parameters determined by near-infrared time-resolved spectroscopy (NIRTRS) under thermoneutral or cold condition and pulmonary oxygen uptake during cold exposure.

Correlation $\left(r^{2}\right)$

\begin{tabular}{|c|c|c|c|c|c|c|c|c|c|c|c|c|c|c|}
\hline \multirow[b]{3}{*}{ Ref. no. } & \multirow[b]{3}{*}{ Instrument } & \multirow[b]{3}{*}{$n$} & \multirow[b]{3}{*}{$\begin{array}{l}\text { Study } \\
\text { design }\end{array}$} & \multirow[b]{3}{*}{ Parameters } & \multicolumn{8}{|c|}{ Correlation $\left(r^{2}\right)$} & & \\
\hline & & & & & \multicolumn{5}{|c|}{ Supraclavicular region } & \multicolumn{4}{|c|}{ Deltoid (forearm) region } & \multirow[b]{2}{*}{$\mathrm{StO}_{2}$} \\
\hline & & & & & $\mu_{\mathrm{s}}^{\prime}$ & $\mathrm{Oxy}-\mathrm{Hb}$ & Deoxy-Hb & Total-Hb & $\mathrm{StO}_{2}$ & $\mu_{\mathrm{s}}{ }^{\prime}$ & Oxy-Hb & Deoxy-Hb & Total-Hb & \\
\hline \multirow[t]{2}{*}{ Nirengi et al. (37) } & NIRTRS & 18 & $\begin{array}{l}\text { Cross- } \\
\text { sectional }\end{array}$ & $\mathrm{CIT} 27^{\circ} \mathrm{C}$ & 0.00 & $0.38^{*}$ & $0.49^{\star}$ & $0.41^{*}$ & 0.14 & 0.09 & 0.06 & 0.04 & 0.06 & 0.04 \\
\hline & & & & $\mathrm{CIT} 19^{\circ} \mathrm{C}$ & 0.08 & $0.24^{\star}$ & 0.16 & $0.23^{\star}$ & 0.01 & 0.15 & 0.02 & 0.09 & 0.04 & 0.06 \\
\hline
\end{tabular}

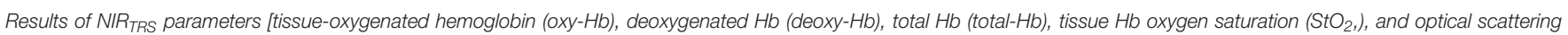
parameters] and cold-induced thermogenesis (CIT) for healthy men under thermoneutral $\left(27^{\circ} \mathrm{C}\right)$ or cold condition $\left(19^{\circ} \mathrm{C}\right)$ are presented.

$\mu_{s}{ }^{\prime}$, reduced scattering coefficient determined by NIRTRS.

${ }^{*} P<0.05$.

$19^{\circ} \mathrm{C}$ for $2 \mathrm{~h}$ with their feet intermittently placed on a clothwrapped ice for $\sim 4 \mathrm{~min}$ every $5 \mathrm{~min}$ (9). A significant correlation was found between $[\text { total-Hb }]_{\text {sup }}$, $[\mathrm{oxy}-\mathrm{Hb}]_{\text {sup }}$, or $[\text { deoxy-Hb }]_{\text {sup }}$ only under thermoneutral conditions and CIT, but not between adjStO ${ }_{2}$ or $\mu_{\mathrm{s}}^{\prime}$ sup and CIT (37). In contrast, previous studies reported a significant correlation in the supraclavicular region between the adjStO $\mathrm{S}_{2}$ and oxygen consumption by BAT under cold environment and between $\mu_{\mathrm{s}}^{\prime}$ sup and $\mathrm{SUV}_{\text {max }}$ and $\mathrm{SUV}$ mean $(29,32)$. It is noted that a personalized cooling protocol may be a better procedure to induce a CIT response personalized to each individual (60). Collectively, although the $[\text { total-Hb }]_{\text {sup }}$, $[\mathrm{oxy}-\mathrm{Hb}]_{\text {sup }}$, and $[\mathrm{deoxy}-\mathrm{Hb}]_{\text {sup }}$ are markers for BAT activity as evaluated by CIT, the adjStO 2 and $\mu_{\mathrm{s}}^{\prime}$ sup become less sensitive to CIT (Table 3).

\section{Relationship Between NIR TRS Parameters in the Supraclavicular Region and Chronological and Anthropometric Data}

${ }^{18}$ FDG-PET/CT studies have revealed that a significant relationship exists between BAT activity and chronological and anthropometrical parameters $(4,5,29,56)$. Cold-stimulated ${ }^{18}$ FDG-PET/CT studies have shown that BAT activity negatively associated with age, sex, BMI, \%BF mass, and VFA, and also that BAT was a significant independent determinant of glucose and HbA1c levels, after adjustment for age, sex, and body adiposity $(10,56)$.

A cross-sectional study using $\mathrm{NIR}_{\mathrm{TRS}}$ demonstrated that [total-Hb] $]_{\text {sup }}$ under warm environment was negatively associated with age and body adiposity in 413 Japanese individuals [a median age of 43.0 (33.0-58.0, interquartile range) years, BMI of $22.5(20.7-24.5) \mathrm{kg} / \mathrm{m}^{2}$, and \%BF of $\left.26.8 \%(20.6-32.3 \%)\right]$ in winter (33) (Figure 1). With the exception of participants in their 20s, there were no sex-related differences in [total$\mathrm{Hb}]_{\text {sup }}$ among the groups tested (Figure 1). Multivariate analyses revealed that the $\% \mathrm{BF}$ and VFA were significantly negatively correlated with [total-Hb] $]_{\text {sup }}$ (33). The observation of the study was analogous to data acquired using ${ }^{18} \mathrm{FDG}-\mathrm{PET} / \mathrm{CT}$, indicating the usefulness of the parameter [total-Hb] sup. In contrast, $\mu_{\mathrm{s}}^{\prime}$ was found to be significantly negatively correlated with some of the anthropometrical parameters. Together, the $[\mathrm{oxy}-\mathrm{Hb}]_{\text {sup }}$ and
[deoxy-Hb] sup displayed similar accuracy to the [total-Hb] sup for detecting relationships with chronological and anthropometric data (Table 4).

\section{Changes in NIR TRS Parameters in the Supraclavicular Region in Response to Ambient Temperature Fluctuations}

BAT increases in winter according to ${ }^{18} \mathrm{FDG}-\mathrm{PET} / \mathrm{CT}$ studies (4, 56-59). However, one study reported that early winter showed higher BAT activity than late winter or early spring (61). A cross-sectional study (35) reported that [total-Hb] sup was higher in winter than in summer. It has also been reported that a lower average ambient temperature during the 4-6 weeks before the measurement day increases [total-Hb] sup (33). This finding is consistent with previous findings reporting that, while BAT activity rose during the winter, a few months are needed for the increase in BAT activity after a decrease in the air temperature (58). A longitudinal study using the same healthy subjects (men/women, 35/23; mean age, 37.4 years; mean BMI, $22.5 \mathrm{~kg} / \mathrm{m}^{2}$; BAT positive rate, 48\%) in summer and winter under thermoneutral conditions revealed a significant increase in $[\text { total-Hb }]_{\text {sup }}$, but not in the reference region or in the $\mu_{\mathrm{s}}{ }^{\prime}$ from any regions (37). It is unclear why $\mu_{\mathrm{s}}^{\prime}$ sup region did not change between summer and winter. However, it is speculated that if triglyceride droplet in the supraclavicular area decreases in winter owing to the increase in BAT (or beiging), the $\mu_{\mathrm{s}}{ }^{\prime}$ should decrease because WAT (triglyceride droplet) obtains high scattering characteristics (62). Thus, even increasing the mitochondria content (the increase in $\mu_{\mathrm{s}}{ }^{\prime}$ ) would offset the decrease in WAT (the decrease in $\mu_{\mathrm{s}}^{\prime}$ ), indicating that [total$\mathrm{Hb}]_{\text {sup }}$ may be a better indicator of BAT activity than $\mu_{\mathrm{s}}^{\prime}$ sup. We demonstrated seasonal changes in other NIR TRS parameters, which supplement previously published findings in Table 5 $(35,37)$. The $\left[\right.$ oxy-Hb] sup and the $[\text { total-Hb }]_{\text {sup }}$ obtain similar tendency for monitoring seasonal fluctuations in BAT-d. In winter, the decrease in the deltoid [deoxy-Hb] demonstrated that muscle metabolism blunted in winter and that this is less reliable than $[\text { oxy-Hb }]_{\text {sup }}$ or [total-Hb $]_{\text {sup }}$ (Table 5).

Collectively, the $[\mathrm{oxy}-\mathrm{Hb}]_{\text {sup }},[\text { total- } \mathrm{Hb}]_{\text {sup }}, \mathrm{StO}_{2 \text { sup }}$, and $\mathrm{adjStO}_{2}$ can detect seasonal fluctuations of BAT-d, which is 


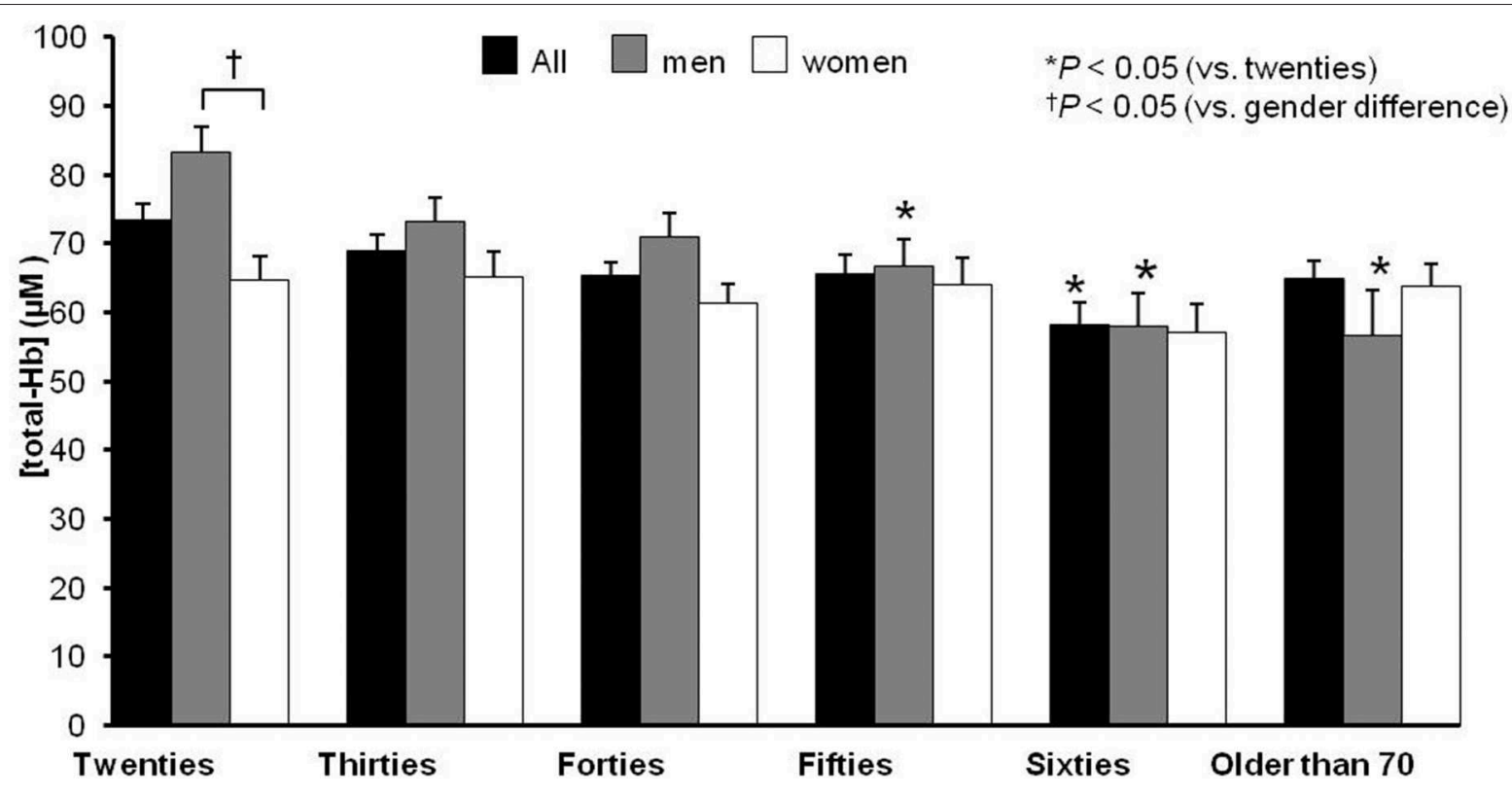

FIGURE 1 | Chronological and sex differences in terms of the concentration of the supraclavicular total hemoglobin [total-Hb], an indicator of brown adipose tissue (BAT). The supraclavicular [total-Hb] potentially containing BAT. The BAT-positive rate (SUV $\max >2.0)$ is indicated in the bottom of the figure based on previous studies $(29,33)$. The values are presented as means \pm standard error (SE), adjusting for body mass index, body fat ratio, and visceral fat area. ${ }^{\circ}$ SPIE. Reproduced by permission of the publisher. Adopted from reference (33).

TABLE 4 | Relationship between parameters in the supraclavicular region obtained by near-infrared time-resolved spectroscopy (NIRTRS) and anthropometric and body composition parameters.

\begin{tabular}{|c|c|c|c|c|c|c|c|c|c|c|}
\hline \multirow[b]{3}{*}{ Ref. no. } & \multirow[b]{3}{*}{ Instrument } & \multirow[b]{3}{*}{$n$} & \multirow[b]{3}{*}{$\begin{array}{l}\text { Study } \\
\text { design }\end{array}$} & \multirow[b]{3}{*}{ Parameters } & \multicolumn{4}{|c|}{ Correlation $\left(r^{2}\right)$} & \multirow[b]{3}{*}{$\mathrm{StO}_{2}$} & \multirow[b]{3}{*}{$\mathrm{AdjStO}_{2}$} \\
\hline & & & & & & upraclavic & region & \multirow[b]{2}{*}{ Total-Hb } & & \\
\hline & & & & & $\mu_{\mathrm{s}^{\prime}}$ & Oxy-Hb & Deoxy-Hb & & & \\
\hline \multirow[t]{4}{*}{ Fuse et al. (33) } & $\mathrm{NIR}_{\text {TRS }}$ & 413 & $\begin{array}{l}\text { Cross- } \\
\text { sectional }\end{array}$ & Age & 0.00 & $0.07^{\star}$ & $0.04^{\star}$ & $0.06^{*}$ & $0.02^{*}$ & NM \\
\hline & & & & $\mathrm{BMl}$ & $0.02^{*}$ & $0.11^{*}$ & $0.12^{*}$ & $0.12^{*}$ & 0.00 & NM \\
\hline & & & & \%body fat & 0.00 & $0.16^{*}$ & $0.10^{*}$ & $0.15^{\star}$ & $0.02^{*}$ & NM \\
\hline & & & & Visceral fat area & $0.01^{*}$ & $0.13^{*}$ & $0.12^{*}$ & $0.14^{\star}$ & 0.00 & NM \\
\hline
\end{tabular}

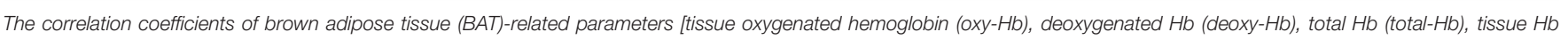
oxygen saturation $\left(\mathrm{StO}_{2}\right.$,), and optical scattering parameters] as determined by NIRTRS and body composition and anthropometric parameters are presented.

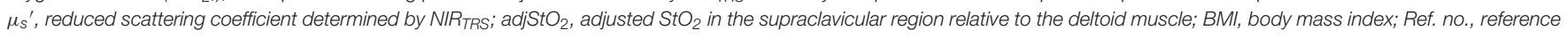
number is obtained from the list of references in this paper; NM, not mentioned.

${ }^{\star} P<0.05$.

consistent with the findings of previous ${ }^{18} \mathrm{FDG}$-PET/CT studies (4, 56-59).

\section{Correlation Between NIRS Parameters in the Supraclavicular Region and Lipid Metabolites}

Finding blood biomolecules correlated with BAT characteristics would permit us to advance human BAT studies because PET/CT studies may be difficult owing to ionizing radiation and cold exposures. Studies on lipidomic profiles have clarified BAT and WAT characteristics according to muscle contractions or cold environment $(11,12,14,16)$. BAT characteristics are related to unique profiles of lipid metabolites, such as the concentration of lysophosphatidylcholine-acyl (LysoPC-acyl) C16:0 in humans (63), and the concentration of phosphatidylethanolamine (PE) in the BAT and WAT was decreased in high-fat diet-fed mice (14). The relationships have been examined in the winter and summer between [total-Hb] sup, a parameter for evaluating BAT-d, measured using $\mathrm{NIR}_{\mathrm{TRS}}$ and plasma lipids in humans (38). Healthy volunteers with [total-Hb] $]_{\text {sup }}$ values over $74.0 \mu \mathrm{M}$ (high BAT-d) were studied $(n=23)$ and control volunteers with lower [total-Hb] $]_{\text {sup }}$ values $<70.0 \mu \mathrm{M}$ (low BAT-d) $(n=$ 23) were tested. Ninety-two plasma samples were examined (23 men and 23 women, aged 21-55; BMI, $21.9 \pm 3.0 \mathrm{~kg} / \mathrm{m}^{2}$, 
$\% \mathrm{BF} 23.3 \pm 8.0 \%$ ), in summer and winter. Using liquid chromatography-time-of-flight-mass spectrometry, plasma lipid profiles were determined. The [total- $\mathrm{Hb}]_{\text {sup }}$ was determined as a parameter of BAT-d using NIR TRS $_{\text {under thermoneutral }}$ conditions. Body composition parameters, such as $\% \mathrm{BF}$ and VFA, were examined. Univariate and multivariate regression analyses were used to determine factors affecting $[\text { total-Hb }]_{\text {sup }}$. In men, there were 37 metabolites showing positive correlations and 20 metabolites showing negative correlations $(P<0.05)$ with $[\text { total- } \mathrm{Hb}]_{\text {sup }}$, respectively. After the $Q$ values were obtained by correcting false discovery rate, only androgens (testosterone, androstanedione, dehydroandrosterone, dehydroepiandrosterone, or epitestosterone) showed a significant $(Q<0.05)$ positive correlation with $[\text { total-Hb }]_{\text {sup }}$ in men in winter. Multivariate regression analysis revealed that $[\text { total- } \mathrm{Hb}]_{\text {sup }}$ showed a significant correlation with androgens in men and VFA in women in winter. Notably, the [total-Hb] sup showed a significant relationship with androgens in winter in men but did not with any body-composition characteristics, such as whole body and visceral adiposity, which are generally associated with [total-Hb $]_{\text {sup }}$. Although androgens deteriorated the BAT capacity in vitro (64), testosterone induced a preferable effect on BAT activity, body adiposity, and energy expenditure in animal models (65-67). Thus, BAT characteristics might be predicted by measuring plasma androgens as a biomarker in men in the winter. However, further detailed research is needed to discover biomarkers that predict BAT in women.

\section{Changes in NIRS Parameters in the Supraclavicular Region by Thermogenic Functional Ingredients}

Recent studies have demonstrated that BAT can improve health status and has a protective effect on lifestyle-related diseases (4$11,13,14)$. Consequently, research has been focused on finding methods for effectively enhancing BAT activity and/or mass $(9,11-14)$. Developed strategies include cold acclimation $(9,11-$ $14)$ and acute treatment of $\beta_{3}$-adrenergic receptor (AR) agonists in humans (68). However, cold exposure intervention would not be easy to apply to daily life (9), and $\beta 3$-AR agonists may elicit unpreferable influence, including a risk for hypertension and increased susceptibility to arterial sclerosis (68). Recent investigations have revealed the mechanisms underlying the effects of thermogenic food ingredients. Pathways involved include the transient receptor potential channels (TRP)-BAT axis, a site of adaptive thermogenesis evoked by $\beta$-adrenoceptor activation (69). The TRP-BAT axis comprises the activation of cold-sensitive TRP channels located in peripheral tissues, such as the skin and intestines. The activation of TRP channels results in the signal delivery through the afferent nerve to the hypothalamus, which then evokes sympathetic nerve activation within BAT. This causes norepinephrine (NE) release, initiating $\beta$-adrenergic tracts to brown adipocytes and eliciting UCP1 upregulation and adaptive thermogenesis (69). In contrast to cold exposure intervention, functional food ingredients may be easily incorporated into daily life. This has been confirmed in animals and humans and includes capsinoids as TRP vanilloid 
1 agonists, catechins as TRPA1/V1 agonists, and so on (70). Furthermore, they have the benefit of having no apparent side effects $(9,34,36,69,70)$.

\section{A}

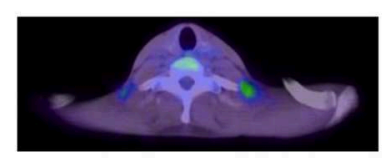

Before

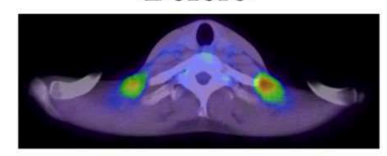

After

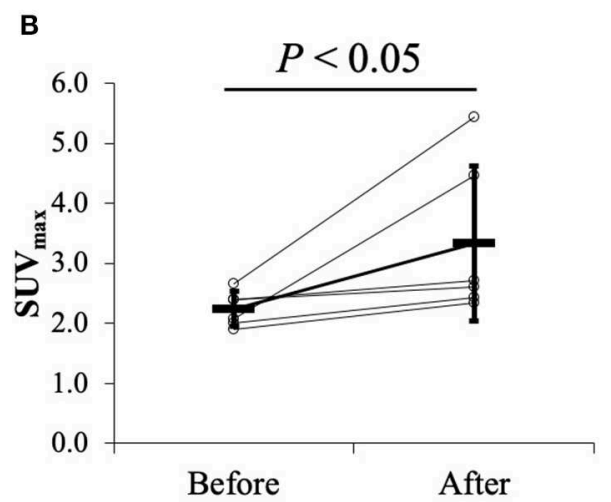

FIGURE 2 | (A) Typical images of the uptake of ${ }^{18} \mathrm{~F}$-fluorodeoxy glucose (FDG) (mean standardized uptake value) before and after the 6-weeks capsiate supplementation in the supraclavicular region. (B) Maximal standardized uptake value (SUV $V_{\text {max }}$ ) pre- and post-supplementation. ${ }^{\circledR}$ SPIE. Reproduced by permission of the publisher. Adopted from reference (34).
Among thermogenic food ingredients, substances, such as capsiate are known to increase BAT activity (9, 70). Previously, the effect of capsiate on [total-Hb] $]_{\text {sup }}$, determined by the NIR TRS $_{\text {, }}$ was examined (34). Twenty healthy individuals [capsiate group $(n=10)$ vs. placebo group $(n=10), 20.7 \pm 1.2$ years vs. $20.9 \pm 0.9$ years; BMI, $21.4 \pm 1.8$ vs. $21.9 \pm 1.0 \mathrm{~kg} / \mathrm{m}^{2} ; \% B F$, $21.3 \pm 7.6 \%$ vs. $22.9 \pm 8.7 \%$ ] were supplemented either with capsiate $(9 \mathrm{mg} /$ day) daily for 8 weeks or a placebo in a paralleled, double-blind manner, and [total- $\mathrm{Hb}]_{\text {sup }}$ was measured during the treatment period, and for an 8-weeks follow-up period under thermoneutral conditions (34). The study also measured BAT activity with ${ }^{18}$ FDG-PET/CT under cold-exposure conditions as previously reported (29). This was only done twice (not every 2 weeks), pre- and post-supplementation, to reduce participant exposure to ionizing radiation. The study demonstrated a parallel change in BAT-d $(+46.4 \%, P<0.05)$ pre- and postsupplementation, evaluated as [total- $\mathrm{Hb}]_{\text {sup }}$, or as BAT activity $(+48.8 \%, P<0.05)$ evaluated as the $\mathrm{SUV}_{\max }$, a parameter of the BAT capacity, by ${ }^{18}$ FDG-PET/CT, after the supplementation of thermogenic capsiate (Figures 2, 3). During the 8-weeks followup period, the [total-Hb] $]_{\text {sup }}$ decreased both in the capsiate and placebo groups; the decrease was greater in the capsiate group (albeit not significantly, $P=0.07$ ) compared to that of the placebo group.

Previous studies examined whether a catechins-rich green tea extract increases energy consumption in humans (7174). Animal studies have shown that catechin intake increases BAT, the effects of which were abolished when the $\beta$-blocker was administrated $(75,76)$. Thus, we used NIR $_{\text {TRS }}$ under thermoneutral conditions to test the effect of sustained catechinrich ingredient $(540 \mathrm{mg} /$ day $)$ intake on $[\text { total- } \mathrm{Hb}]_{\text {sup }}$ and investigated potential associations between changes in [total$\mathrm{Hb}]_{\text {sup }}$ and body adiposity in 22 healthy women college students [catechin group $(n=10)$ vs. placebo group $(n=11), 21.1$

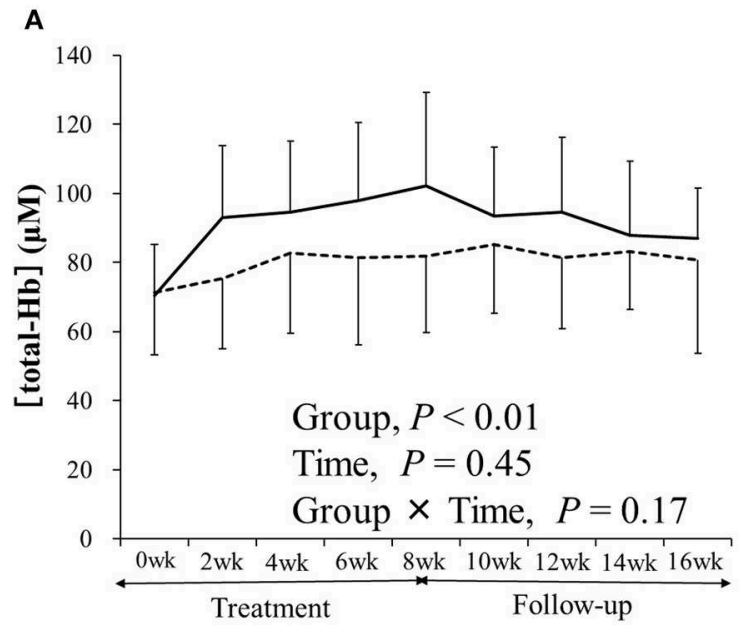

B

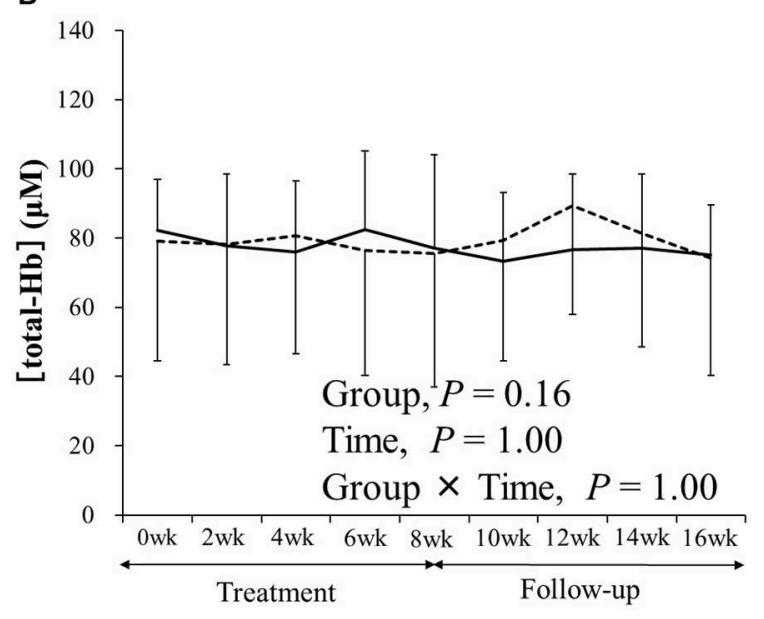

FIGURE 3 | The concentration of total hemoglobin [total-Hb], an indicator of brown adipose tissue (BAT) in (A) the supraclavicular fossa potentially containing BAT and (B) the deltoid, a control region. Adopted from Nirengi et al. (34). ${ }^{\circledR}$ SPIE. Reproduced by permission of the publisher. 
\pm 2.0 years vs. $20.5 \pm 2.1$ years; $\mathrm{BMI}, 21.1 \pm 1.3$ vs. 20.9 $\pm 1.6 \mathrm{~kg} / \mathrm{m}^{2}$; \%BF, $24.0 \pm 3.5 \%$ vs. $\left.25.8 \pm 7.6 \%\right]$ (36). That study revealed that the [total-Hb] sup was elevated by $19 \%$ in the catechin group only after 12 weeks (36). As for the $\mu_{s}{ }^{\prime}$, which was not documented in the previous study, it did not change during catechin ingestion. There was a significant negative relationship between the enhancement in [total-Hb $]_{\text {sup }}$ and the decrease in extramyocellular lipids, an indicator for possible insulin insensitivity (77), in the vastus lateralis muscle determined by proton-magnetic resonance spectroscopy $(r=-0.66, P<0.05)$.

After further analysis, some of which has not been documented in the previous study (34), capsiate supplementation was shown to cause a significant increase in [total-Hb] $]_{\text {sup }}$, [oxy$\mathrm{Hb}]_{\text {sup }}$, and [deoxy-Hb $]_{\text {sup }}$ and, upon its withdrawal, a decrease in $[\text { total-Hb }]_{\text {sup }}$, [oxy-Hb $]_{\text {sup }}, \mathrm{StO}_{2 \text { sup }}$, and adjStO $\mathrm{St}_{2}$ (Table 6). Similarly, by the catechins intervention, the [oxy-Hb $]_{\text {sup }}$, [deoxy$\mathrm{Hb}]_{\text {sup }}, \mathrm{StO}_{2 \text { sup }}$, and adjStO $\mathrm{S}_{2}$ obtain the same result as the [total$\mathrm{Hb}]_{\text {sup }}$ for assessing increases in BAT-d (36). Collectively, studies into functional ingredient supplementation using NIR TRS suggest that $[\mathrm{oxy}-\mathrm{Hb}]_{\text {sup }}$ and $[\text { total- } \mathrm{Hb}]_{\text {sup }}$ are particularly suitable for the evaluation of BAT-d in intervention studies where the use of ${ }^{18}$ FDG-PET/CT is not applicable (Table 6).

\section{Limitations and Perspectives}

The studies using NIRS contain several limitations. Several optical issues should be considered, as the multilayer, inhomogeneous tissue property created by skin, adipose tissue, and muscle may affect in vivo tissue scattering and absorption characteristics and modulation of optical path. In a study (39), the optical characteristics in the deltoid, abdominal, and supraclavicular regions were tested using $\mathrm{NIR}_{\mathrm{TRS}}$. The results indicate that there are unique region-specific relationships between [total-Hb] and $\mu_{s}{ }^{\prime}$, suggesting that examining the [total- $\mathrm{Hb}]-\mu_{\mathrm{s}}^{\prime}$ relationship is a practical way to distinguish BAT from other tissues. It could be noted that due to the nature of optical measurements, the placement of the optodes for the NIRTRS must be always secure and in the same area, especially during longitudinal studies. Although NIRTRS is able to quantify tissue oxygen dynamics, the values are affected by optical characteristics underlying subcutaneous adipose tissue in the supraclavicular region, which varies depending on the body composition of subjects, thereby influencing NIR $_{\text {TRS }}$ measurements. The reason is that the values obtained is diluted by the lower $[\mathrm{Hb}]$ in the subcutaneous adipose tissue (78). The $[\text { total- } \mathrm{Hb}]_{\text {sup }}$ values can be recalculated by considering the thickness of the adipose layer (79).

As no change in the [total- $\mathrm{Hb}]_{\text {sup }}$ and $\mu_{\mathrm{s}}^{\prime}$ sup was observed during 2-h conditions at $19^{\circ} \mathrm{C}$ compared to baseline conditions at

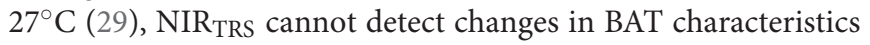
responding to an acute cold exposure in nature because NIR $R_{T R S}$ is insensitive to changes in the blood flow $(33,35-37)$. However, a newly developed NIRTRS system contains six wavelengths $(760,800,830,908,936$, and $976 \mathrm{~nm})$, of which the latter three wavelengths are adopted to detect optical characteristics of lipids and water (80). This system could provide information on the changes in tissue water and lipid content in response to acute interventions, such as experimental cold exposure, which cannot 
be obtained using the conventional three-wavelength NIRTRS $_{T}$ system. The new six-wavelength $\mathrm{NIR}_{\mathrm{TRS}}$ system could contribute further insight on the chronic as well as acute responsiveness of BAT metabolism in humans.

Finally, future studies should obtain further evidence to validate BAT evaluation using NIR TRS $_{\text {because }}{ }^{18}$ FDG-PET/CT measurements include several limitations. BAT mainly consumes intracellular lipids, as well as plasma non-esterified fatty acids and those derived from lipoproteins-whereas ${ }^{18}$ FDG$\mathrm{PET} / \mathrm{CT}$ measures a glucose analog. The lack of standardization when quantifying BAT by ${ }^{18} \mathrm{FDG}-\mathrm{PET} / \mathrm{CT}$ is also a problem. Thus, additional experiments to reach this conclusion are required, such as (1) examining whether NIR $_{\text {TRS }}$ parameters actually represent the in vivo mitochondrial density of BAT, or are related to molecules implicated in the vascularization and thermogenesis of BAT [e.g., vascular endothelial-cell growth factor (VEGF), UCP-1, peroxisome proliferator-activated receptor $\gamma$ coactivator 1- $\alpha$ (PGC1- $\alpha)$ ]. This could be carried out by taking human biopsies from the supraclavicular area and examining the relationship between $\mathrm{NIR}_{\mathrm{TRS}}$ parameters and the molecular signature of this tissue; (2) using other radiotracers beyond ${ }^{18} \mathrm{~F}-\mathrm{FDG}$, such as ${ }^{15} \mathrm{O}, \mathrm{H}_{2}^{15} \mathrm{O}, \mathrm{C}^{15} \mathrm{O}$, or ${ }^{11} \mathrm{C}$-acetate, which will allow to measure the real oxygen consumption, tissue perfusion, and metabolic activity of human BAT and which are more likely to represent the thermogenic nature or activity of this tissue than ${ }^{18} \mathrm{~F}-\mathrm{FDG}$; (3) carrying out studies where the kinetics of $\mathrm{NIR}_{\mathrm{TRS}}$ are related to the kinetics of the metabolic activity of BAT (dynamic PET/CT); (4) using different cooling protocols, aiming to standardize the cooling stress to which individuals are submitted (avoiding potential biases in individual BAT activation); and (5) performing reliability studies to examine

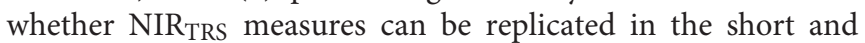
long term.

\section{CONCLUSION}

Correlation coefficients are presented for parameters determined by NIRS and ${ }^{18}$ FDG-PET/CT, CIT, or anthropometric and body composition parameters. Significant correlations were found between [total-Hb $]_{\text {sup }},[\text { oxy- } \mathrm{Hb}]_{\text {sup }}$, [deoxy-Hb $]_{\text {sup }}$, $\mu_{\text {s sup, }}^{\prime} \mathrm{StO}_{2 \text { sup }}$, or adjStO 2 and ${ }^{18} \mathrm{FDG}-\mathrm{PET} / \mathrm{CT}$ indicators; between $[\text { total-Hb }]_{\text {sup }},[\mathrm{oxy}-\mathrm{Hb}]_{\text {sup }}$, or $[\text { deoxy-Hb }]_{\text {sup }}$ and

\section{REFERENCES}

1. Chondronikola M, Sidossis LS. Brown and beige fat: from molecules to physiology. Biochim Biophys Acta. (2019) 1864:91-103. doi: 10.1016/j.bbalip.2018.05.014

2. Davis TRA, Johnston DR, Bell FC, Cremer BJ. Regulation of shivering and nonshivering heat production during acclimation of rats. Am J Physiol Legacy Content. (1960) 198:471-5. doi: 10.1152/ajplegacy.1960.198.3.471

3. Rothwell NJ, Stock MJ. A role for brown adipose tissue in diet-induced thermogenesis. Nature. (1979) 281:31-5. doi: 10.1038/281031a0

4. Saito M, Okamatsu-Ogura Y, Matsushita M, Watanabe K, Yoneshiro T, NioKobayashi J, et al. High incidence of metabolically active brown adipose tissue in healthy adult humans: effects of cold exposure and adiposity. Diabetes. (2009) 58:1526-31. doi: 10.2337/db09-0530
CIT; and between $[\text { total-Hb }]_{\text {sup }}$, $[\text { oxy-Hb }]_{\text {sup }}$, or $[\text { deoxy-Hb }]_{\text {sup }}$ and anthropometric and body composition indicators. The

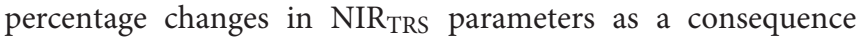
of either seasonal temperature fluctuations or dietary supplementation with thermogenic ingredients are presented. Seasonal temperature fluctuations influenced [total- $\mathrm{Hb}]_{\text {sup }}$, $[\mathrm{oxy}-\mathrm{Hb}]_{\text {sup }}, \mathrm{StO}_{2 \text { sup }}$, and $\mathrm{adjStO}_{2}$. Studies on thermogenic capsinoid or catechin supplementation revealed a significant increase in $[\text { total-Hb }]_{\text {sup }}$, $[\mathrm{oxy}-\mathrm{Hb}]_{\text {sup }}$, and $[\text { deoxy-Hb }]_{\text {sup }}$. Upon withdrawal of these supplements, a decrease in [total- $\mathrm{Hb}]_{\text {sup }}$, $[\text { oxy-Hb }]_{\text {sup }}, \mathrm{StO}_{2 \text { sup }}$, and $\mathrm{adjStO}_{2}$ was seen. Recently, androgens were found to show a significant positive correlation with [total$\mathrm{Hb}]_{\text {sup }}$ only in men in winter. Thus, BAT characteristics might be predicted by measuring plasma androgens as a biomarker in men in the winter.

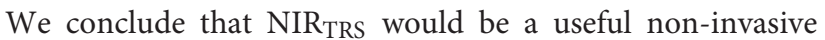
technology for assessing BAT-d, although further validation is still needed. Among the parameters evaluated by $\mathrm{NIR}_{\mathrm{TRS}}$, the $[\mathrm{oxy}-\mathrm{Hb}]_{\text {sup }}$ as well as [total-Hb] $]_{\text {sup }}$ would be applicable to assessing BAT characteristics in both cross-sectional and interventional studies.

\section{AUTHOR CONTRIBUTIONS}

$\mathrm{TH}, \mathrm{SN}, \mathrm{SF}$, and YK collected the relevant literature and wrote the manuscript. SA, RK, MK, and TE assisted in illustrations, formatting, and collection of literature. NS, MM, MS, and TY coordinated and edited the relevant discussion on PET/CT measurements and BAT.

\section{FUNDING}

We have been granted by Japan Society for the Promotion of Science (15H03100 and 19H04061), which is an independent administrative institution, established by way of a national law for the purpose of contributing to the advancement of science in all fields of the natural and social sciences and the humanities.

\section{ACKNOWLEDGMENTS}

This work was supported by JSPS KAKENHI (15H03100 and 19H04061).

5. Cypess AM, Lehman S, Williams G, Tal I, Rodman D, Goldfine AB, et al. Identification and importance of brown adipose tissue in adult humans. $N$ Engl J Med. (2009) 360:1509-17. doi: 10.1056/NEJMoa 0810780

6. van Marken Lichtenbelt WD, Vanhommerig JW, Smulders NM, Drossaerts JMAFL, Kemerink GJ, Bouvy ND, et al. Cold-activated brown adipose tissue in healthy men. N Engl J Med. (2009) 360:1500-8. doi: 10.1056/NEJMoa 0808718

7. Virtanen KA, Lidell ME, Orava J, Heglind M, Westergren R, Niemi T, et al. Functional brown adipose tissue in healthy adults. N Engl J Med. (2009) 360:1518-25. doi: 10.1056/NEJMoa0808949

8. Pfannenberg C, Werner MK, Ripkens S, Stef I, Deckert A, Schmadl M, et al. Impact of age on the relationships of brown adipose tissue with sex and adiposity in humans. Diabetes. (2010) 59:1789-93. doi: 10.2337/db10-0004 
9. Yoneshiro T, Aita S, Matsushita M, Kayahara T, Kameya T, Kawai Y, et al. Recruited brown adipose tissue as an antiobesity agent in humans. J Clin Invest. (2013) 123:3404-8. doi: 10.1172/JCI67803

10. Matsushita M, Yoneshiro T, Aita S, Kameya T, Sugie H, Saito M. Impact of brown adipose tissue on body fatness and glucose metabolism in healthy humans. Int J Obes. (2014) 38:812-7. doi: 10.1038/ijo.2013.206

11. Hanssen MJW, van der Lans AAJJ, Brans B, Hoeks J, Jardon KMC, Schaart $\mathrm{G}$, et al. Short-term cold acclimation recruits brown adipose tissue in obese humans. Diabetes. (2016) 65:1179-89. doi: 10.2337/db15-1372

12. Hanssen MJW, Hoeks J, Brans B, van der Lans AAJJ, Schaart G, van den Driessche JJ, et al. Short-term cold acclimation improves insulin sensitivity in patients with type 2 diabetes mellitus. Nat Med. (2015) 21:863-5. doi: 10.1038/nm.3891

13. Blondin DP, Labbé SM, Tingelstad HC, Noll C, Kunach M, Phoenix S, et al. Increased brown adipose tissue oxidative capacity in cold-acclimated humans. J Clin Endocrinol Metab. (2014) 99:E438-46. doi: 10.1210/jc.2013-3901

14. van der Lans AAJJ, Hoeks J, Brans B, Vijgen GHEJ, Visser MGW, Vosselman MJ, et al. Cold acclimation recruits human brown fat and increases nonshivering thermogenesis. J Clin Invest. (2013) 123:3395-403. doi: 10.1172/JCI68993

15. Cypess AM, Lehman S, Williams G, Tal I, Rodman D, Goldfine AB, et al. Identification and importance of brown adipose tissue in adult humans. $N$ Engl J Med. (2009) 360:1509-17. doi: 10.3201/eid1910.130203

16. Borga M, Virtanen KA, Romu T, Leinhard OD, Persson A, Nuutila P, et al. Brown adipose tissue in humans: detection and functional analysis using PET (positron emission tomography), MRI (magnetic resonance imaging), and DECT (dual energy computed tomography). Methods Enzymol. (2014) 537:141-59. doi: 10.1016/B978-0-12-411619-1.00008-2

17. Chen KY, Cypess AM, Laughlin MR, Haft CR, Hu HH, Bredella MA, et al. Brown adipose reporting criteria in imaging STudies (BARCIST 1.0): recommendations for standardized FDG-PET/CT experiments in humans. Cell Metab. (2016) 24:210-22. doi: 10.1016/j.cmet.2016.07.014

18. Koskensalo K, Raiko J, Saari T, Saunavaara V, Eskola O, Nuutila P, et al. Human brown adipose tissue temperature and fat fraction are related to its metabolic activity. J Clin Endocrinol Metab. (2017) 102:1200-7. doi: 10.1210/jc.2016-3086

19. Sun L, Verma S, Michael N, Chan SP, Yan J, Sadananthan SA, et al. Brown adipose tissue: multimodality evaluation by PET, MRI, infrared thermography, and whole-body calorimetry (tactical-ii). Obesity. (2019) 27:1434-42. doi: 10.1002/oby.22560

20. Thuzar M, Law WP, Dimeski G, Stowasser M, Ho KKY. Mineralocorticoid antagonism enhances brown adipose tissue function in humans: a randomized placebo-controlled cross-over study. Diabetes Obes Metab. (2018) 21:509-16. doi: 10.1111/dom.13539

21. Baron DM, Clerte M, Brouckaert P, Raher MJ, Flynn AW, Zhang H, et al. In vivo noninvasive characterization of brown adipose tissue blood flow by contrast ultrasound in mice. Circ Cardiovasc Imaging. (2012) 5:652-9. doi: 10.1161/CIRCIMAGING.112.975607

22. Ong FJ, Ahmed BA, Oreskovich SM, Blondin DP, Haq T, Konyer NB, et al. Recent advances in the detection of brown adipose tissue in adult humans: a review. Clin Sci. (2018) 32:1039-54. doi: 10.1042/CS20170276

23. Franz D, Weidlich D, Freitag F, Holzapfel C, Drabsch T, Baum T, et al. Association of proton density fat fraction in adipose tissue with imaging-based and anthropometric obesity markers in adults. Int J Obes. (2018) 42:175-82. doi: 10.1038/ijo.2017.194

24. Gifford A, Towse TF, Walker RC, Avison MJ, Welch EB. Characterizing active and inactive brown adipose tissue in adult humans using PET-CT and MR imaging. Am J Physiol Endocrinol Metab. (2016) 311:E95-104. doi: 10.1152/ajpendo.00482.2015

25. Law JM, Morris DE, Astle V, Finn E, Muros JJ, Robinson LJ, et al. Brown adipose tissue response to cold stimulation is reduced in girls with autoimmune hypothyroidism. J Endocr Soc. (2019) 3:2411-26. doi: $10.1210 /$ js.2019-00342

26. El Hadi H, Frascati A, Granzotto M, Silvestrin V, Ferlini E, Vettor R, et al. Infrared thermography for indirect assessment of activation of brown adipose tissue in lean and obese male subjects. Physiol Meas. (2016) 37:N118-28. doi: 10.1088/0967-3334/37/12/N118

27. Cypess AM, Haft CR, Laughlin MR, Hu HH. Brown fat in humans: consensus points and experimental guidelines. Cell Metab. (2014) 20:408-15. doi: 10.1016/j.cmet.2014.07.025
28. Kamiya A, Michikami D, Iwase S, Mano T. Decoding rule from vasoconstrictor skin sympathetic nerve activity to nonglabrous skin blood flow in humans at normothermic rest. Neurosci Lett. (2008) 439:13-7. doi: $10.1016 /$ j.neulet.2008.04.018

29. Nirengi S, Yoneshiro T, Sugie H, Saito M, Hamaoka T. Human brown adipose tissue assessed by simple, noninvasive near-infrared time-resolved spectroscopy. Obesity. (2015) 23:973-80. doi: 10.1002/oby.21012

30. Cinti S. Transdifferentiation properties of adipocytes in the adipose organ. Am J Phys Endocrinol Metab. (2009) 297:E977-86. doi: 10.1152/ajpendo.00183.2009

31. Beauvoit B, Chance B. Time-resolved spectroscopy of mitochondria, cells and tissues under normal and pathological conditions. Mol Cell Biochem. (1998) 184:445-55.

32. Muzik O, Mangner TJ, Leonard WR, Kumar A, Janisse J, Granneman JG. 15O PET measurement of blood flow and oxygen consumption in cold-activated human brown fat. J Nuclear Med. (2013) 54:523-31. doi: 10.2967/jnumed.112.111336

33. Fuse S, Nirengi S, Amagasa S, Homma T, Kime R, Endo T, et al. Brown adipose tissue density measured by near-infrared time-resolved spectroscopy in Japanese, across a wide age range. J Biomed Opt. (2018) 23:1-9. doi: 10.1117/1.JBO.23.6.065002

34. Nirengi $\mathrm{S}$, Homma $\mathrm{T}$, Inoue $\mathrm{N}$, Sato $\mathrm{H}$, Yoneshiro $\mathrm{T}$, Matsushita $\mathrm{M}$, et al. Assessment of human brown adipose tissue density during daily ingestion of thermogenic capsinoids using near-infrared time-resolved spectroscopy. J Biomed Opt. (2016) 21:091305. doi: 10.1117/1.JBO.21.9. 091305

35. Nirengi S, Sakane N, Amagasa S, Wakui S, Homma T, Kurosawa Y, et al. Seasonal differences in brown adipose tissue density and pulse rate variability in a thermoneutral environment. J Physiol Anthropol. (2018) 37:6. doi: 10.1186/s40101-018-0166-x

36. Nirengi S, Amagasa S, Homma T, Yoneshiro T, Matsumiya S, Kurosawa $\mathrm{Y}$, et al. Daily ingestion of catechin-rich beverage increases brown adipose tissue density and decreases extramyocellular lipids in healthy young women. SpringerPlus. (2016) 5:1363. doi: 10.1186/s40064-016-3029-0

37. Nirengi S, Fuse $S$, Amagasa $S$, Homma $T$, Kime $R$, Kuroiwa $M$, et al. applicability of supraclavicular oxygenated and total hemoglobin evaluated by near-infrared time-resolved spectroscopy as indicators of brown adipose tissue density in humans. Int J Mol Sci. (2019) 20:2214. doi: 10.3390/ijms20092214

38. Fuse S, Sugimoto M, Kurosawa Y, Kuroiwa M, Aita Y, Tomita A, et al. Relationships between plasma lipidomic profiles and brown adipose tissue density in humans. Int J Obes. (2020). doi: 10.1038/s41366-020-0558-y. [Epub ahead of print].

39. Fuse $S$, Hamaoka $T$, Kuroiwa $M$, Kime $R$, Endo $T$, Tanaka $R$, et al. Identification of human brown/beige adipose tissue using nearinfrared time-resolved spectroscopy. In: Biophotonics in Exercise Science, Sports Medicine, Health Monitoring Technologies, and Wearables (2020). doi: $10.1117 / 12.2545273$

40. Acosta FM, Berchem J, Martinez-Tellez B, Sanchez-Delgado G, Alcantara JMA, Ortiz-Alvarez L, et al. Near-infrared spatially resolved spectroscopy as an indirect technique to assess brown adipose tissue in young women. $\mathrm{Mol}$ Imaging Biol. (2019) 21:328-338. doi: 10.1007/s11307-018-1244-5

41. Jöbsis FF. Noninvasive, infrared monitoring of cerebral and myocardial oxygen sufficiency and circulatory parameters. Science. (1977) 198:1264-7. doi: 10.1126/science.929199

42. Delpy DT, Cope M. Quantification in tissue near-infrared spectroscopy. Philos Trans R Soc Lond B Biol Sci. (1997) 352:649-59. doi: 10.1098/rstb.1997.0046

43. Ferrari M, Mottola L, Quaresima V. Principles, techniques, and limitations of near infrared spectroscopy. Can J Appl Physiol. (2004) 29:463-87. doi: 10.1139/h04-031

44. Chance B, Dait MT, Zhang C, Hamaoka T, Hagerman F. Recovery from exercise-induced desaturation in the quadriceps muscles of elite competitive rowers. Am J Phys Cell Physiol. (1992) 262:C766-75. doi: 10.1152/ajpcell.1992.262.3.C766

45. Chance B, Nioka S, Kent J, McCully K, Fountain M, Greenfeld R, et al. Time-resolved spectroscopy of hemoglobin and myoglobin in resting and ischemic muscle. Anal. Biochem. (1988) 174:698-707. doi: 10.1016/0003-2697(88)90076-0

46. Hamaoka T, McCully KK. Review of early development of nearinfrared spectroscopy and recent advancement of studies on muscle 
oxygenation and oxidative metabolism. J Physiol Sci. (2019) 69:799-811. doi: 10.1007/s12576-019-00697-2

47. Hamaoka T, Katsumura T, Murase N, Nishio S, Osada T, Sako T, et al. Quantification of ischemic muscle deoxygenation by near infrared timeresolved spectroscopy. J Biomed Opt. (2000) 5:102-5. doi: 10.1117/1.429975

48. Hamaoka T, McCully KK, Quaresima V, Yamamoto K, Chance B. Nearinfrared spectroscopy/imaging for monitoring muscle oxygenation and oxidative metabolism in healthy and diseased humans. J Biomed Opt. (2007) 12:062105. doi: 10.1117/1.2805437

49. Gunadi S, Leung TS, Elwell CE, Tachtsidis I. Spatial sensitivity and penetration depth of three cerebral oxygenation monitors. Biomed Opt Express. (2014) 5:2896-912. doi: 10.1364/BOE.5.002896

50. Chance B, Leigh JS, Miyake H, Smith DS, Nioka S, Greenfeld R, et al. Comparison of time-resolved and -unresolved measurements of deoxyhemoglobin in brain. Proc Natl Acad Sci USA. (1988) 85:4971-5. doi: 10.1073/pnas.85.14.4971

51. Stebbings GK, Morse CI, McMahon GE, Onambele GL. Resting arterial diameter and blood flow changes with resistance training and detraining in healthy young individuals. J Athl Train. (2013) 48:209-19. doi: 10.4085/1062-6050-48.1.17

52. Ferreira LF, Hueber DM, Barstow TJ. Effects of assuming constant optical scattering on measurements of muscle oxygenation by nearinfrared spectroscopy during exercise. J Appl Phys. (2007) 102:358-67. doi: 10.1152/japplphysiol.00920.2005

53. Blondin DP, Labbé SM, Phoenix S, Guérin B, Turcotte ÉE, Richard D, et al. Contributions of white and brown adipose tissues and skeletal muscles to acute cold-induced metabolic responses in healthy men. J Phys. (2015) 593:701-14. doi: 10.1113/jphysiol.2014.283598

54. u Din M, Raiko J, Saari T, Kudomi N, Tolvanen T, Oikonen V, et al. Human brown adipose tissue $[15 \mathrm{O}] \mathrm{O}_{2}$ PET imaging in the presence and absence of cold stimulus. Eur J Nucl Med Mol Imaging. (2016) 43:1878-86. doi: 10.1007/s00259-016-3364-y

55. Sanchez-Delgado G, Martinez-Tellez B, Garcia-Rivero Y, Alcantara JMA, Acosta FM, Amaro-Gahete FJ, et al. Brown adipose tissue and skeletal muscle ${ }^{18} \mathrm{~F}$-FDG activity after a personalized cold exposure is not associated with cold-induced thermogenesis and nutrient oxidation rates in young healthy adults. Front Physiol. (2018) 9:1577. doi: 10.3389/fphys.2018.01577

56. Yoneshiro T, Aita S, Matsushita M, Kameya T, Nakada K, Kawai Y, et al. Brown adipose tissue, whole-body energy expenditure, and thermogenesis in healthy adult men. Obesity. (2011) 19:13-6. doi: 10.1038/oby.2010.105

57. Cohade C, Mourtzikos KA, Wahl RL. "USA-Fat": prevalence is related to ambient outdoor temperature-evaluation with 18F-FDG PET/CT. J Nuclear Med. (2003) 44:1267-70.

58. Au-Yong ITH, Thorn N, Ganatra R, Perkins AC, Symonds ME. Brown adipose tissue and seasonal variation in humans. Diabetes. (2009) 58:2583-87. doi: 10.2337/db09-0833

59. Yoneshiro T, Matsushita M, Nakae S, Kameya T, Sugie H, Tanaka S, et al. Brown adipose tissue is involved in the seasonal variation of cold-induced thermogenesis in humans. Am J Physiol Regul Integr Comp Physiol. (2016) 310:R999-1009. doi: 10.1152/ajpregu.00057.2015

60. Martinez-Tellez B, Sanchez-Delgado G, Garcia-Rivero Y, Alcantara JMA, Martinez-Avila WD, Muñoz-Hernandez M V., et al. A new personalized cooling protocol to activate brown adipose tissue in young adults. Front Physiol. (2017) 8:863. doi: 10.3389/fphys.2017.00863

61. Kim S, Krynyckyi BR, Machac J, Kim CK. Temporal relation between temperature change and FDG uptake in brown adipose tissue. Eur J Nucl Med Mol Imaging. (2008) 35:984-9. doi: 10.1007/s00259-007-0670-4

62. Yang Y, Soyemi OO, Landry MR, Soller BR. Influence of a fat layer on the near infrared spectra of human muscle: quantitative analysis based on twolayered monte carlo simulations and phantom experiments. Opt Express. (2005) 13:1570-9. doi: 10.1364/opex.13.001570

63. Boon MR, Bakker LEH, Prehn C, Adamski J, Vosselman MJ, Jazet IM, et al. LysoPC-acyl C16:0 is associated with brown adipose tissue activity in men. Metabolomics. (2017) 13:48. doi: 10.1007/s11306-017-1185-z

64. Varlamov O, White AE, Carroll JM, Bethea CL, Reddy A, Slayden O, et al. Androgen effects on adipose tissue architecture and function in nonhuman primates. Endocrinology. (2012) 153:3100-10. doi: 10.1210/en.2011-2111

65. Cannon B, Nedergaard J. Brown adipose tissue: function and physiological significance. Physiol Rev. (2004) 84:277-359. doi: 10.1152/physrev.00015.2003
66. Law J, Bloor I, Budge H, Symonds ME. The influence of sex steroids on adipose tissue growth and function. Horm Mol Biol Clin Investig. (2014) 19:13-24. doi: 10.1515/hmbci-2014-0015

67. Yanase $\mathrm{T}$, Fan WQ, Kyoya K, Min L, Takayanagi R, Kato S, et al. Androgens and metabolic syndrome: Lessons from androgen receptor knock out (ARKO) mice. J Steroid Biochem Mol Biol. (2008) 109:254-7. doi: 10.1016/j.jsbmb.2008.03.017

68. Cypess AM, Weiner LS, Roberts-Toler C, Elía EF, Kessler SH, Kahn PA, et al. Activation of human brown adipose tissue by a $\beta 3$-adrenergic receptor agonist. Cell Metab. (2015) 21:33-8. doi: 10.1016/j.cmet.2014. 12.009

69. Cannon B, Nedergaard J. Nonshivering thermogenesis and its adequate measurement in metabolic studies. J Exp Biol. (2011) 214:242-53. doi: 10.1242/jeb.050989

70. Saito M, Yoneshiro T. Capsinoids and related food ingredients activating brown fat thermogenesis and reducing body fat in humans. Curr Opin Lipidol. (2013) 24:71-7. doi: 10.1097/MOL.0b013e32835a4f40

71. Yoneshiro T, Matsushita M, Hibi M, Tone H, Takeshita M, Yasunaga K, et al. Tea catechin and caffeine activate brown adipose tissue and increase coldinduced thermogenic capacity in humans. Am J Clin Nutr. (2017) 105:873-81. doi: $10.3945 /$ ajcn.116.144972

72. Dulloo AG, Seydoux J, Girardier L, Chantre P, Vandermander J. Green tea and thermogenesis: interactions between catechin-polyphenols, caffeine and sympathetic activity. Int J Obes Relat Metab Disord. (2000) 24:252-8. doi: 10.1038/sj.ijo.0801101

73. Gosselin C, Haman F. Effects of green tea extracts on non-shivering thermogenesis during mild cold exposure in young men. Br J Nutr. (2013) 110:282-8. doi: 10.1017/S0007114512005089

74. Hursel R, Westerterp-Plantenga MS. Catechin- and caffeine-rich teas for control of body weight in humans. Am J Clin Nutr. (2013) 98:1682S-93S. doi: $10.3945 /$ ajcn.113.058396

75. Nomura S, Ichinose T, Jinde M, Kawashima Y, Tachiyashiki K, Imaizumi $\mathrm{K}$. Tea catechins enhance the mRNA expression of uncoupling protein 1 in rat brown adipose tissue. J Nutr Biochem. (2008) 19:840-7. doi: 10.1016/j.jnutbio.2007.11.005

76. Choo JJ. Green tea reduces body fat accretion caused by high-fat diet in rats through beta-adrenoceptor activation of thermogenesis in brown adipose tissue. J Nutr Biochem. (2003) 14:671-6. doi: 10.1016/j.jnutbio.2003. 08.005

77. Hausman GJ, Basu U, Du M, Fernyhough-Culver M, Dodson M V. Intermuscular and intramuscular adipose tissues: bad vs. good adipose tissues. Adipocyte. (2014) 3:242-55. doi: 10.4161/adip.28546

78. McCully KK, Hamaoka T. Near-infrared spectroscopy: what can it tell us about oxygen saturation in skeletal muscle? Exerc Sport Sci Rev. (2000) 28:123-7.

79. Yamamoto K, Niwayama M, Kohata D, Kudo N, Hamaoka T, Kime R, et al. Functional imaging of muscle oxygenation using a 200-channel cw NIRS system. In: BiOS 2001 The International Symposium on Biomedical Optics, San Jose, CA (2001). p. 142-52.

80. Suzuki H, Ohmae E, Yoshimoto K, Wada H, Homma S, Suzuki N, et al. Water and lipid contents measured at various parts of the human body with a sixwavelength time-resolved spectroscopy system. Opt Tomogr Spectrosc Tissue XIII. (2019) 10874:108740A. doi: 10.1117/12.2507429

Conflict of Interest: The authors declare that the research was conducted in the absence of any commercial or financial relationships that could be construed as a potential conflict of interest.

The reviewer FA declared a past co-authorship with one of the authors TH to the handling editor.

Copyright (c) 2020 Hamaoka, Nirengi, Fuse, Amagasa, Kime, Kuroiwa, Endo, Sakane, Matsushita, Saito, Yoneshiro and Kurosawa. This is an open-access article distributed under the terms of the Creative Commons Attribution License (CC BY). The use, distribution or reproduction in other forums is permitted, provided the original author(s) and the copyright owner(s) are credited and that the original publication in this journal is cited, in accordance with accepted academic practice. No use, distribution or reproduction is permitted which does not comply with these terms. 